less and most undesirable office. One member of the Faculty who held the office for several years, accepted it reluctantly after much persuasion.

The several difficulties above referred to were never of such moment as to interefere seriously with the steady development of the institution; the number of students increased continuously, a high standard was always maintained, and the good will of the community was manifested by benefactions of increasing frequency and magnitude. Never were such evidences of public appreciation so marked, as in the year ending with June, 1899, at which time the new president was elected.

The Faculty had long desired the guidance of a wise president, and to President Ayers the members at once extended the assurance of their cordial co-operation and support. This attitude was not reciprocated.

From the published statement of the special committee of the Board, we infer that the president had been fully imbued with the ideas of members of the Board who were opposed to the Faculty. He had asked and received almost absolute power. How he has used this power is known. He was made the sole channel of communication between the Faculty and the Board, and he has made himself the judge as to what communications should reach the Board. In more than one instance he has withheld from the Board orderly communications addressed to it, and duly entrusted to him for transmission.

The summary dismissal of the Faculty, in the face of excellent work accomplished and recorded year after year, raised a storm of public indignation. A committee of prominent citizens, numbering over twenty-five was organized and a subcommittee was then appointed to make a thorough investigation and report. This committee was hard at work for several weeks.

It is in evidence that in October, soon after the opening of the term, the President gave a dinner at his house to the members of the Board, and that on this occasion he asked and received pledges of support in whatever he might recommend in the way of changes in the Faculty.

Whatever may have been the advice given to the President, he seems to have surpassed all expectations. Members of the Board have expressed surprise and dissatisfaction, but under the cireumstances they felt under obligation to support the new administration.

In conclusion, I refer, for the benefit of all who desire detailed information, to the 'Final Report of the Citizens' Committee on University Affairs' which will soon be issued in pamphlet form. A synopsis of the pamphlet is as follows :

1. Unauspioious opening of the college year.

2. Abrupt and sweeping demand for resignations.

3. Emphatic protest and peremptory resignation of Professor Myers in an open letter.

4. Public opinion finds expression in the organization of a citizens' committee which forms a subcommittee for investigation.

5. Report of subcommittee to the general committee of eitizens. Much light thrown on the situation. The Faculty vindicated and President Ayers arraigned. The subcommittee instructed to appear in behalf of the Faculty at the next meeting of the Board.

6. Pleas for justice before the Board of Directors. A publio hearing of the Faculty requested. A petition of the Faculty for an open investigation returned to the writers by reason of an alleged informality. Special committee of the Board appointed to draw up a reply to the citizens' committee and report at a special meeting. The minority denied representation.

7. The special committee of the Board makes an elaborate report. Indiscriminate accusations. General defense of the Board and of the President. The request of citizens refused. A hearing not granted.

8. Resignation of Professor French. The report accompanying the resignation not presented by the President, although addressed to the Board of Direotors. The Board declines to hear the report when a demand therefor is made by one of its members.

9. Remarkable admissions by President Ayers.

10. The report of Professor French.

11. Review of the Board's defense.

Any one may obtain a copy of this pamphlet by addressing W. N. Hobart, 243 East Pearl street, Cincinnati, Ohio.

All official statements and reports, pertinent to both sides of the question, are given in full.

Cincinnati, April 10, 1900. Thomas French, JR.

\section{INFORMATION WANTED.}

THE psychophysiology of anæsthesia is a productive subject greatly in need of adequate investigation and discussion. Both purie science and practical surgery have doubtless much to gain from a deeper-going study of experiences 
under ether, chloroform, nitrous oxide, etc., than has as yet been made. Scientific literature has frequently contained accounts of isolated individual experiences reported most often because of their strangeness. A very large number of descriptions of the ordinary experiences is what is now desired, and to this end blanks have been prepared on which replies to certain simple questions may be written. All persons, and especially hospital surgeons, officers of medical societies, and instructors in medical schools, are respectfully requested to send to the undersigned for as many of these blanks as they care to distribute among persons who have been under an anæsthetic. These will be gratefully sent, and received when filled out.

George V. N. Dearborn.

\section{Physiological Laboratory, Harvard Medical Schoot, Boston, Mass.}

\section{NOTE ON THE PIGMENTS OF THE COCCID CHIONASPIS FURFURA, FITCH.}

I HAVE just had occasion to examine some specimens of Chionaspis furfura sent me by Professor C. A. Keffer, from Tennessee, and in so doing, I found some pigments which may be of interest to others than coccidologists. The female $C$. furfura is brown-pink, but on being placed in liquor potassæ immediately becomes olive-green. The addition of hydrochloric acid at once restores the brown-pink color, showing that the two are simply acid and alkaline phases of one pigment, the living female having an acid reaction. These two colors are strikingly like those seen in the feathers of certain birds, namely the jacana, and the herons of the subgenera Hydranassa and Butorides; the resemblance being so close as to suggest that the maroon and green colors of these birds are likewise due to two phases of a pigment closely similar to that of the Chionaspis. The eggs of C. furfura, abundantly present in the material examined, are purplish-pink, with orange portions due to an oil or fat. The oil retains the same brilliant orange color even after boiling in caustic potash, but collects in globules varying from 6 to $60 \mu$ diameter. The purplish-pink pigment is turned Prussian-green by liquor potassæ, but in a short while this again alters to a clear indigo blue. The latter change is hastened by boiling. On adding hydrochloric acid, the blue becomes reddish-purple. The egg-pigment is therefore similar to that of the mother insect, yet apparently not identical.

\section{T. D. A. Cock EReLL.}

Mesilla Park, New Mexico, March 31, 1900.

\section{CURRENT NOTES ON PHYSIOGRAPHY. PORTO RICO.}

R. T. HILL has prepared some 'Notes on the Forest Conditions of Porto Rico' (U. S. Dep't Agric., Forestry Bull. 25), which are prefaced by a description of the island's configuration and by a plate taken from a relief model. The discontinuous axial sierra, steeper to south than north and mostly of volcanic rock, is of rug. ged aspect, less than 3500 feet in height. The mountains do not rise to a single crest line, but form a sea of conical peaks and beaded ridges, elaborately dissected by numerous ravines and valleys between knife-edged spurs of graded slope. Here habitations find no place in the narrow valley floors but occupy the mountain sides, where heavy rainfall and deep-weathered tenacious soil support a luxurious vegetation; coffee and tobacco are cultivated to the very summits. The sierra is surrounded by a narrow and broken 'collar' of limestone, forming coastal hills of heights up to 500 feet or more, round or dome-like in form, with few ravines; here the surface is sheeted with a thin red argillaceous residual soil. South of the sierra, where the climate is relatively dry, the hills are mostly covered with thorny vegetation or chapparal. Longitudinal valleys sometimes separate the hills from the sierra; transverse valleys divide the hills into groups separated by wide alluvial floors which open into triangular plains (filled estuaries) occupied by sugar plantations on nearing the coast. A great part of the island has been cleared of its original forest. The 3268 square miles of the island contain 26,650 farms, which therefore average 7.4 to the square mile; but much land once cultivated, is now 'ruinate' from long use without fertilizers or from soil-washing.

The 'Water Resources of Porto Rico' are described by H. M. Wilson (Water Supply and 